\title{
Studi Perbandingan Kuat Tarik Tidak Langsung terhadap Campuran Aspal Beton dengan menggunakan Limbah Marmer dan Abu Sekam Padi sebagai Filler
}

\author{
St. Fauziah Badaron ${ }^{1}$, Alimin Gecong ${ }^{2}$, Muh. Kasim Anies ${ }^{3}$, Wahyuni Meydinia Aunila Achmad ${ }^{4}$, Eka Putri \\ Setiani $^{5}$ \\ 1,2,3,4,5 Program Studi Teknik Sipil Fakultas Teknik Universitas Muslim Indonesia \\ Jl. Urip Sumoharjo KM 05 Makassar, Sulawesi Selatan

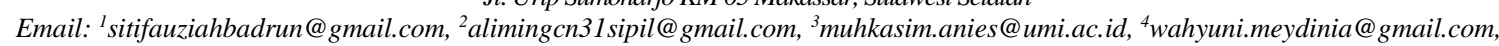 \\ ${ }^{5}$ ekasetiany15@gmail.com
}

\section{Kata Kunci}

Kuat tarik tidak

langsung; limbah marmer; abu sekam padi; filler.

\begin{abstract}
Abstrak
Lapisan perkerasan jalan mengalami dua pembebanan yaitu beban tekan dan beban tarik. Pada kondisi dilapangan beban tarik lebih sering menyebabkan retak, diawali dengan adanya retakawal (crackinitation) pada bagian bawah lapisan perkerasan yang kemudian akan menjalar kepermukaan. Salah satu upaya yang dapat dilakukan untuk mengatasinya yaitu dengan menambahkan bahan alternative yang dapat menunjang kekuatan perkerasan. Beberapa bahan tambah yang dapat digunakan yaitu limbah marmer dan abu sekam padi sebagai bahan pengisi (filler). Penelitian ini bertujuan untuk mengetahui kadaraspal optimum untuk pencampuran limah marmer dan abu sekam padi sebagai filler serta untuk mengetahui pengaruh limbah marmer dana buse kampa di pada campuran terhadap kuat tarik tidak langsung. Pengujian awal dengan alat Marshall Test untuk mendapatkan kadar aspal optimum (KAO). Pengujian selanjutnya dengan menggunakan alat Indirect Tensile Strenght. KAO yang digunakan yaitu $5,95 \%$ dan kadar filler yaitu $0,0 \%, 0,5 \%, 1,0 \%, 1,5 \%$, dan 2,0\%. Dari hasil pengujian kuat tarik tidak langsung, campuran dengan menggunakan filler limbah marmer mampu menahan beban sebesar 11969,37 KPa. Sedangkan campuran yang menggunakan abu sekam padi mampu menahan beban sebesar 11294,47 KPa. Berdasarkan hasil tersebut maka dapat disimpulkan bahwa campuran dengan menggunakan filler abu marmer lebih kuat menahan beban dibandingkan abu sekam padi.
\end{abstract}

\section{Abstract}

The pavement layer passes two loads: the compressive load and the tensile load. On surface conditions, itis discover ed by retrie ving the crack in itation at the bottom fthe layer which will then radiate to the surface. One of eff or that can be done to over come this is to add

Keywords

Indirect tensile strength; marble waste; rice husk ash; filler. alternative material stoin crease the strength of it. Some of the ingredients added can beused are marble waste and rice husk ashas filler. This study aim stode termine the optimal asphalt content formixing marble andri cehuskash waste asa filler and also to know the marble and gray waste on in direct tensil emixture. Initial test with Marshall Test tool to obtain optimum bitumen content (KAO). Then exttestis by using the Indirect Tensile Strenght tool. KAO is $5.95 \%$ and filler content is $0.0 \%, 0.5 \%, 1.0 \%, 1.5 \%$, and $2.0 \%$. In directtax collection, using afiller of marble wast ecapable of with standing loads of $11969.37 \mathrm{KPa}$. While the mixture using rice huskas hable to with stand the load of $11294.47 \mathrm{KPa}$. Base on the results it can be concluded that the mixtureusing as hmarble filler is stronger to with stand the load than using rice husk ash.

\section{PENDAHULUAN}

Jalan merupakan peranan yang sangat penting dalam menunjang kelancaran transportasi bagi pertumbuhan suatu daerah, sehingga dibutuhkan perkerasan jalan yang baik agar lalu lintas menjadi aman, nyaman dan lancar. Lapisan perkerasan jalan mengalami dua pembebanan yaitu beban tekan dan beban tarik. Pada kondisi di lapangan beban tarik lebih sering menyebabkan retak, diawali dengan adanya retak awal (crack initation) pada bagian bawah lapisan perkerasanyang kemudian akan menjalar kepermukaan. 
Untuk mendapatkan pembebanan gaya tarik yang terjadi di lapangan, yaitu menggunakan metode Indirect Tensile Strength Test. Uji kuat tarik tidak langsung ialah kemampuan bahan untuk menerima beban secara terus menerus, sehingga akan mengakibatkan tegangan (stress) yang akan di ikuti dengan kenaikan regangan sampai pada regangan (strain) tertentu, yaitu saat dimana keadaan benda uji mulai retak sehingga terjadi tegangan maksimum. (GarrickdanBiskur,1990)

Filler adalah salah satu bahan penyusun lapis perkerasan yang sifatnya mengisi rongga. Namun mempunyai fungsi yang sangat penting untuk memodifikasi gradasi agregat halus dalam campuran aspal, sehingga kepadatan campuran bisa meningkat. Pada umumnya jenis filler yang digunakan dalam pencampuran aspal beton yaitu abu batu, jika digunakan terus menerus tanpa mencari alternatif jenis fillerlainnya maka ketersediaan abu batu tersebut menjadi berkurang seiring semakin tinggi kebutuhan sarana transportasi yakni jalan raya. Maka dari itu kami mencoba menggunakan bahan alternatif yaitu limbah marmer dan abu sekam padi sebagai filler.

Marmer diperoleh dari alam melalui penambangan. Pada proses pemotongan dan penggergajian sisa serbuk batu marmer yang Masih dibiarkan begitu saja di sekitar daerah penambangan dan belum di manfaatkan secara maksimal dan tepat. Adapun dampak yang paling menonjol ialah polusi udara debu-debu marmer yang dapat mengganggu pernafasan dan juga mengotori lingkungan. Limbah marmerberupaserbuk berwarna putih kemerahan, apa bila limbah marmer dicampur dengan air maka akan mengeras, karena berupa serbuk yang dapat berfungsi sebagai bahan pengikat. Melihat potensinyaupaya lain untuk pemanfaatan limbah marmer adalah digunakan sebagai filler dalam campuran aspal beton.

Abu sekam adalah sisa gabah dari pertanian padi yang dibakar sampai menjadi debu memiliki sifat simentasi yang berfungsi meningkatkan kekesatan antara butir partikel. Keberadaan sekam padi atau kulit padi yang melimpah umumnya banyak dijumpai didaerah persawahan. Namun sekam padi belum termanfaatkan dengan baik, sehingga bernilai guna rendah. Secara visual abu sekam padi merupakan material berwarna abu-abu dengan bentuk butiran yang halus, padat dan bulat.

Seiring meningkatnya permintaan akan kebutuhan material untuk memproduksi beton yang bahan dasar agregat pasir semakin meningkat. Peningkatan jumlah ini diperkirakan akan terus mengalami kenaikan di tahun-tahun berikutnya sehingga upaya peningkatan kualitas hasil produk bata beton perlu dilakukan dengan cara mengevaluasi kekuatan dan karakteristik bahan yang digunakan (Sulaiman \& Nurhidayah, 2018). Diperlukan usaha alternatif pengganti atau subtitusi demi keberlangsungan (sustainable) pembangunan infrastruktur dan industry (Sulaiman, 2018). Oleh karena itu dilakukan penelitian untuk melihat pengaruh kuat tarik tidak langsung pada campuran aspal beton terhadap limbah marmer dan abu sekam padi sebagai filler diharapkan mampu meningkatkan karakteristik campuran aspal beton yaitu nilai stabilitas dan kuat tarik tidak langsung sehingga campuran lebih kuat memikul beban lalu lintas dan lebih tahan terhadap deformasi. Dalam istilah sehari-hari gaya sering diartikan sebagai dorongan atau tarikan. Bila kita menarik atau mendorong suatu benda, berarti kita memberikan gaya pada benda itu (Sulaeman, 2018).

Tujuan penelitian ini adalah untuk mengetahui Kadar Aspal Optimum yang digunakan pada pencampuran aspal beton dengan menggunakan limbah marmer dan abu sekam padi sebagai filler, serta Untuk mengetahui kekuatan pengaruh limbah marmer dan abu sekam padi sebagai filler terhadap kuat tarik tidak langsung.

\section{METODELOGI}

\subsection{Lokasi Penelitian}

Penelitian ini dilakukan di Laboratorium Jalan Raya Dan Transportasi, Fakultas Teknik, Universitas Muslim Indonesia.

\subsection{Bahan dan Alat Penelitian}

a) Bahan Penelitian

Aspal yang digunakan yaitu Aspal Minyak penetrasi 60/70 (AC 60/70) produksi Pertamina yang diperoleh dari PU Bina Marga Baddoka.

Agregat yang digunakan yaitu Agregat kasar dan halus yang diambil secara acakdi stone crusher Bilibili, disatukan kemudian dilakukan pengambilan sampel di laboratorium dengan metode perempatan yang mewakili sampel lainnya. Sedangkan Limbah marmer diperoleh dari Kab. Pangkep Provinsi Sulawesi Selatan dan abu sekam padi diperolehdari Kab.Sidrap Provinsi Sulawesi Selatan.

b) Alat Penelitian

Penelitian ini menggunakan alat-alat yang tersedia di Laboratorium Jalan Raya Dan transportasi FakultasTeknik Universitas Muslim Indonesia. 
Studi Perbandingan Kuat Tarik Tidak Langsung terhadap Campuran Aspal Beton dengan menggunakan Limbah Marmer dan Abu Sekam Padi sebagai Filler

St. Fauziah Badaron, Alimin Gecong, Muh. Kasim Anies, Wahyuni Meydinia Aunila Achmad, Eka Putri Setiani

\subsection{Tahapan Penelitian}

a) Pengambilan bahan benda uji

Persiapan dan pemeriksaan aspal dilaksanakan di Laboratorium Jalan Raya dan Transportasi Jurusan Teknik Sipil Fakultas Teknik Universitas Muslim Indonesia. Serta bahan subtitusi adalah limbah marmer dan abu sekam padi, dimana limbahmarmerdiperoleh dari Kab.Pangkep, Sulawesi Selatan dan abu sekam padi diperoleh dari Kab. Sidrap, Sulawesi Selatan.

b) Pengujian Bahan Benda Uji

Setelah proses persiapan sudah selesai, maka semua bahan penyusun aspal harus di uji di laboratorium, sehingga bahan- bahan yang akan digunakan memenuhi syarat sebagai bahan penyusun aspal beton.

c) Pembuatan Benda Uji

Pembuatan benda uji di lakukan setelah bahan-bahan penyusun aspal beton telah melalui pemeriksaan dan memenuhi syarat sesuai dengan ketentuan. Rencana bendaujiyangakan dibuat berdasarkan pada gradasi agregat campuran dengan bahan campuran variasi limbah marmer dan abu sekam padi sebagai filler.

Kadar Aspal Optimum (KAO) dapat ditentukan dengan memvariasikan kadar aspal rencana dari 4,5\%, 5\%, $5,5 \%, 6 \%, 6,5 \%$ dan dibuat benda uji sebanyak 3(tiga) buah briket untuk masing-masing kadar aspal (total 15 briket untuk keseluruhan kadar aspal).

Beberapa parameter campuran yang dianjurkan oleh Bina Marga untuk dipenuhi dalam penentuan KAO adalah stabilitas, kelelehan (flow), Marshall Quotient (MQ), rongga udara dalam campuran (VIM) dan rongga terisi aspal (VFB). Setelahdi dapatkan KAO maka ditentukan perencanaan campuran filler berdasarkan peraturan Bina Marga 2010 dengan variasi $0 \%, 0,5 \%, 1,0 \%, 1,5 \%$, dan maksimal2,0\%

\subsection{Metode Analisis Data}

Metode yang digunakan dalam mengelola data yaitu metode analisis regresi. Banyak analisis statistik bertujuan untuk mengetahui apakah ada hubungan antara dua atau lebih variabel. Bila hubungan demikian dapat dinyatakandalambentuk rumusmatematik, maka kita akan dapat menggunakannya untuk keperluan peramalan. Seberapa jauh peramalan tersebut dapat dipercaya bergantung pada keeratan hubungan antara variabel-variabel dalam rumus tersebut (Walpole,1995).

Tujuan menggunakan metode analisis regresi ialah untuk membua testi masi rata- rata dan nilai variabel tergantung dengan didasarkan pada nilai variasi bebas. Dan juga untuk meramalkan nilai rata-rata variable bebas dengan didasarkan pada nilai variabel bebas diluar jangkauan sampel. Keselarasan model regresi dapat diterangkan dengan menggunakan nilai R2. Jika nilai R2 sebesar 1 akan mempunyai arti kesesuaian yang sempurna. Seluruh variasi dalam variable Y dapat diterangkan oleh model regresi. Sebaliknya jika R2 sama dengan 0 maka tidak ada hubungan linier antara $\mathrm{X}$ dan $\mathrm{Y}$.

\section{HASIL DAN PEMBAHASAN}

\subsection{Analisis dan Hasil Pengujian Marshall Test untuk Penentuan Kadar Aspal Optimum (KAO)}

Sebelum kita melakukan analisis dari hasil pengujian Marshall Test, kita menghitung karakteristik campuran aspal yang terdiri dari Stabilitas, Flow, Void in Mixture (VIM), Void in Mineral Aggregates (VMA), Void Filled with Asphalt (VFA), Density dan Marshall Quotient dengan menggunakan Metode Marshall Test terlebih dahulu dari hasil pengujian Laboratorium lalu kemudian didapatkan hasilperhitungan karakteristik Marshall dengan 5 variasi kadar aspal yang akan digunakan yaitu kadar aspal 4,5\%, 5,0\%, 5,5\%,6,0\%,dan 6,5\%. Berikut merupakan hasil rekapitulasi karakteristik Marshall dapat dilihat pada table berikut:

Tabel 1. Rekapitulasi pengujian marshall campuran AC - WC pen 60/70 untuk kadar aspal optimum (KAO)

\begin{tabular}{ccccccc}
\hline $\begin{array}{c}\text { Sifat-sifat } \\
\text { campuran }\end{array}$ & \multicolumn{5}{c}{ Hasil Pengujian } & \multirow{2}{*}{ Spesifikasi } \\
\cline { 1 - 6 } Kadar Aspal; $\%$ & 4,5 & 5 & 5,5 & 6 & 6,5 & \\
\hline Density & 2,205 & 2,222 & 2,243 & 2,250 & 2,259 & $22.2 \mathrm{~kg} / \mathrm{mm}^{3}$ \\
VIM; \% & 7,452 & 6,086 & 4,542 & 3,809 & 2,730 & $3-5 \%$ \\
VMA; $\%$ & 17,462 & 17,255 & 16,910 & 17,101 & 17,181 & $215 \%$ \\
VFA; $\%$ & 57,329 & 64,749 & 73,148 & 78,979 & 85,335 & $263 \%$ \\
Stabilitas; $\mathrm{kg}$ & 1067,18 & 1100,42 & 1140,73 & 1116,55 & 1092,36 & $800-1800 \mathrm{~kg}$ \\
Flow; mm & 3,42 & 3,47 & 3,48 & 3,53 & 3,70 & $2-4 \mathrm{~mm}$ \\
MQ; $\mathrm{kg} / \mathrm{mm}$ & 312,837 & 317,661 & 327,809 & 311,571 & 295,298 & Min $250 \mathrm{~kg} / \mathrm{mm}$ \\
\hline
\end{tabular}


Berdasarkan hasil pengujian, maka diperoleh nilai kadar aspal terhadap karakteristik campuran seperti pada Tabel 1. Dari hasil pengujian tersebut kita dapat menentukan nilai KAO. Semua nilai hasil pengujian dimasukkan kedalam grafik untuk mengetahui perlakuan yang terjadi sesuai dengan hubungan antara kadar aspal terhadap karakteristik campuran tersebut.

a. Hubungan Kadar Aspal terhadap Stabilitas

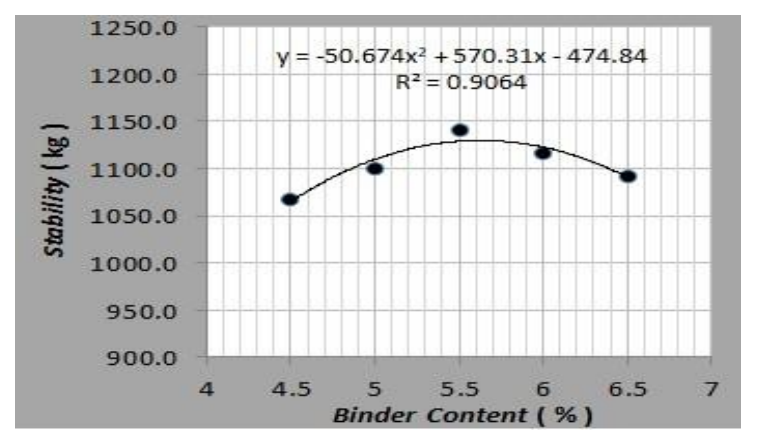

Gambar 1. Hubungan antara kadar aspal terhadap stabilitas

Dari hasil analisis grafik gamar 1 menunjukkan bahwa campuran dengan kadaraspal 4,5\% hingga kadar aspal 6,5\% memenuhi spesifikasi. Semakin besar nilai kadar aspal yang digunakanakan meningkatkan nilai stabilitas hingga kadar aspal optimum. Tetapi seiring dengan penambahan kadar aspalmaka stabilitasnya akan menurun karena campuran akan mengalami kegemukan atau bleding. Karena tebal selimut aspal bertambah dan dapat mengurangi sifat saling kunci antara agregat. Semakin besar nilai stabilitas yang di dapatkan, maka semakin besar juga nilai Flow (ketahanan terhadap kelelehan). Nilai tersebut dapat dilihat pada Tabel 1. Karena, hubungan antara stabilitas denngan Flow berbanding lurus. Semakin besar nilai flow, maka kemampuan aspal beton menerima beban berulang yang diakibatkan oleh beban lalulintas semakin kuat sehingga lapisan aspal beton akan tetap stabil.

b. Hubungan Kadar Aspal terhadap Flow

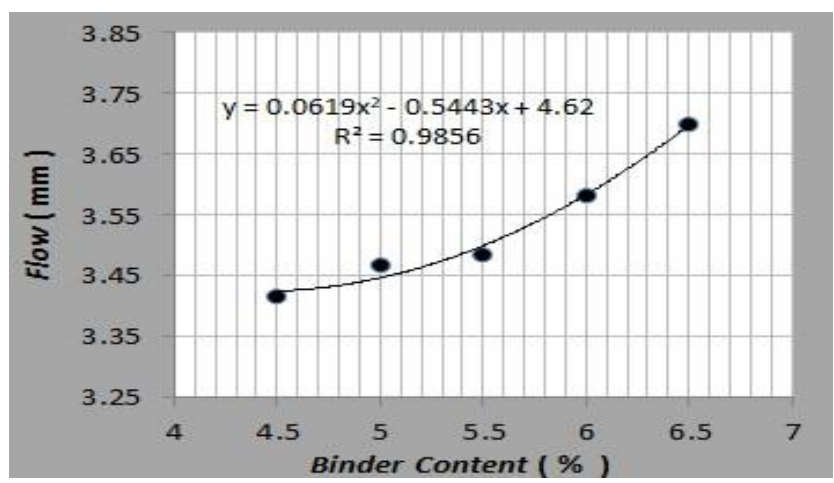

Gambar 2. Hubungan antara kadar aspal terhadap flow

Dari hasil analisis grafik 2. menunjukan bahwa nilai flow dari kadar aspal 4,5\% mengalami peningkatan sampai kadar aspal 6,5\%. Hal ini menjelaskan bahwa campuran lebih tahan terhadap deformasi atau perubahan bentuk yang akan terjadi pada campuran. Semakin besar nilai flow maka semakin besar juga nilai stabilitas. Karena hubungan flow dengan stabilitas berbanding lurus. Begitu juga dengan VIM. Apabila VIM pada campuran tinggi dapat mengakibatkan kelelehanyang lebih cepat. Hal ini dapat diketahui dengan membandingkan antara grafik Flow (Grafik 2.) dengan grafik VIM (Grafik 3.). 
Studi Perbandingan Kuat Tarik Tidak Langsung terhadap Campuran Aspal Beton dengan menggunakan Limbah Marmer dan Abu Sekam Padi sebagai Filler

St. Fauziah Badaron, Alimin Gecong, Muh. Kasim Anies, Wahyuni Meydinia Aunila Achmad, Eka Putri Setiani

c. Hubungan Kadar Aspal terhadap Void in Mixture (VIM)

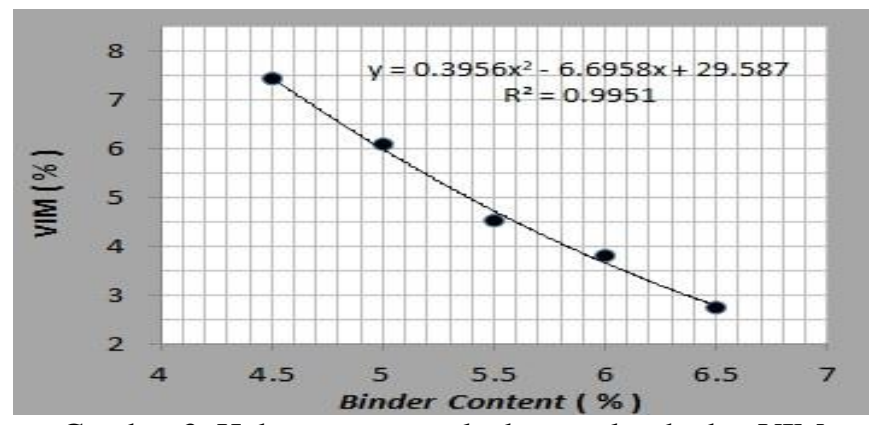

Gambar 3. Hubungan antara kadar aspal terhadap VIM

Dari hasil analisis grafik 3. Menunjukkan bahwa nilai VIM pada kadar aspal 4,5\% mengalami penurunan nilai presentase volume rongga campuran sampai kadar aspal selanjutnya. Campuran dengan kadar aspal $6,5 \%$ tidak memenuhi spesifikasi. Hal ini menggambarkan bahwa volume rongga yang berisi udara pada campuran semakin mengalami penurunan persentase rongga akibat penambahan kadar aspal. Semakin kecil nilai VIM pada campuran maka semakin semakin besar nilai VMA. Karena, apabila persentase rongga yang terdapat pada campuran semakin kecil, maka persentase rongga diantara butir agregat yang tertutupi aspal semakin besar. Namun, apabila kadar aspal berlebihan aspalakan naik ke permukaan sehingga kadar aspal optimum yang dapat mengisi rongga yang kurang tertutup atau menutupi semua rongga.

d. Hubungan Kadar Aspal terhadap Void in Mineral Aggregates (VMA)

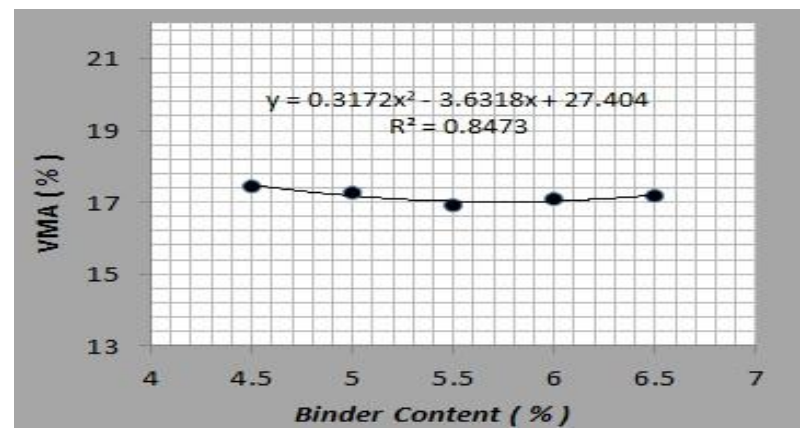

Gambar 4. Hubungan antara kadar aspal terhadapVMA

Dari hasil analisis grafik 4. menunjukkan bahwa, setiap variasi kadar aspal pada campuran secara menyeluruh memenuhi nilai VMA pada campuran berdasarkan spesifikasi Bina Marga yaitu minimal 15\%. Semakin tinggi kadar aspal dalam campuran maka semakin tinggi nila iVMA dalam campuran. Nilai VMA yang terdapat di antara butir-butir agregat yang telah di dapatkan, termaksud didalamnya rongga udara (VIM) dan rongga berisi aspal semua memenuhi spesifikasi. Hal ini menggambarkan bahwa rongga yang terdapat pada campuran untuk semu akadar aspal dengan nilai VMA sudah sesuai dengan besarnya rongga yang seharusnya dimiliki oleh suatu campuran.

e. Hubungan Kadar Aspal terhadap Void Filled in Asphalt (VFA)

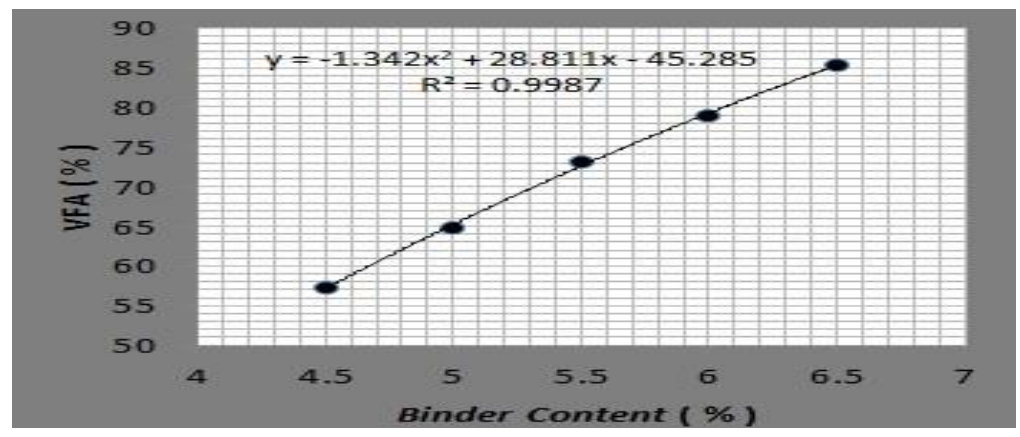


Void Filled with Asphalt (VFA) adalah rongga dalam agregat yang terisi aspal yang dinyatakan dalam persentase (\%) terhadap rongga antar butiran agregat (VMA). Nilai antara Voidsin Mineral Aggregates (VMA) dengan Void Filled with Asphalt (VFA) memiliki katerkaitan yang artinya rongga pada agregat yang terisiaspal adalah bagian dariVMA yang merupakan rongga diantara agregat yang terisioleh aspal. Hasil analisis grafik 3.5 menunjukkan bahwa pada kadar aspal4,5\%nilaiVFA naik sampai pada kadar aspal 6,5\%. Semakain tinggi kadar aspal dalam campuran maka semakin tinggi nilai VFA dalam campuran. Kadaraspal 5\% hingga kadar aspal 6,5\% telah memenuhi spesifikasi. Hal ini menunjukkan bahwa, nilaiVFA atau persentase volume rongga yang berisi aspal mengalami kenaikan seiring bertambahnya kadar aspal yang di gunakan. Hal ini disebabkan oleh besarnya kadar aspal yang mengisi rongga agregat sehingga bukan hanya rongga pada agregat yang akan terisi oleh aspal melainkan rongga yang terdapat diantara butiran agregat (VIM) juga terisi oleh aspal. Pada kadar aspal 4,5\% persentase VFA belum memenuhi spesifikasi artinya kadar aspal yang digunakan kurang sehingga volume rongga juga yang terisi menjadi kurang. Semakin besar nilai VFA pada campuran maka semakin kecil nilai VIM. Hal ini menujukkan bahwa semakin besar pula rongga yang dapat terisi aspal sehingga campuran akan semakin baik.

\section{f. Hubungan Kadar Aspal terhadap Density}

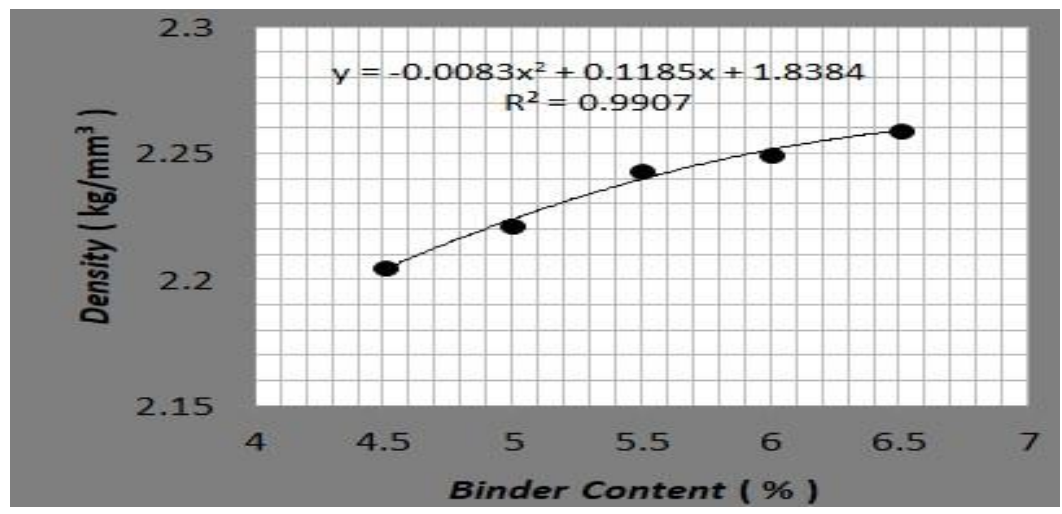

Gambar 6 Hubungan antara kadar aspal terhadap Density

Dari hasil analisis grafik 6. menjelaskan bahwa nilai densityataukepadatan pada kadar aspal 4,5\% nilai density naik sampai kadar aspal 6,5\%. Kadar aspal 4,5\% hingga 6,5\% nilai density campuran telah memenuhi spesifikasi. Semakin besar kadar aspal yang digunakan pada campuran maka semakin tinggi nilai density atau kepadatan yang dihasilkan. Nilai density berbanding lurus dengan VFA. Karena, semakin tinggi persentase rongga yang tertutupi oleh aspal maka kepadatan campuran tersebut juga akan semakin tinggi.

\section{g. Hubungan Kadar Aspal terhadap Marshall Quotient}

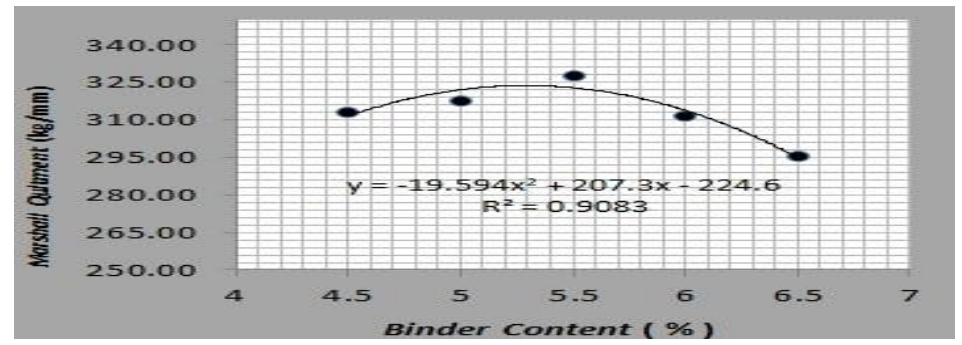

Gambar 7. Hubungan antara kadar aspal terhadap Marshall Quotient

Dari hasil analisis grafik 7. menunjukkan bahwa terjadi peningkatan nilai Marshall Quotien tmulai dari kadar aspal 4,5\% hingga kadar aspal 5,5\% kemudian terjadi penurunan pada kadar aspal 6,0\% hingga kadar aspal 6,5\%.

Namun nilai MQ pada kadar aspal 5,0\% lebih tinggi diantara yang lain. Nilai MQ pada semua kadar aspal memenuhi spesifikasi. Nilai MQ menunjukkan fleksibilitas campuran yaitu semakin besar nilai MQ pada suatu campuran maka akan cenderung terlalu kaku dan mudah retak. Demikian juga bila semakin kecil nilai MQ maka campuran menjadi terlalu lentur dan cenderung kurang stabil. 
Studi Perbandingan Kuat Tarik Tidak Langsung terhadap Campuran Aspal Beton dengan menggunakan Limbah Marmer dan Abu Sekam Padi sebagai Filler

St. Fauziah Badaron, Alimin Gecong, Muh. Kasim Anies, Wahyuni Meydinia Aunila Achmad, Eka Putri Setiani

h. Hubungan Kadar Aspal dengan Karakteristik Campuran Aspal

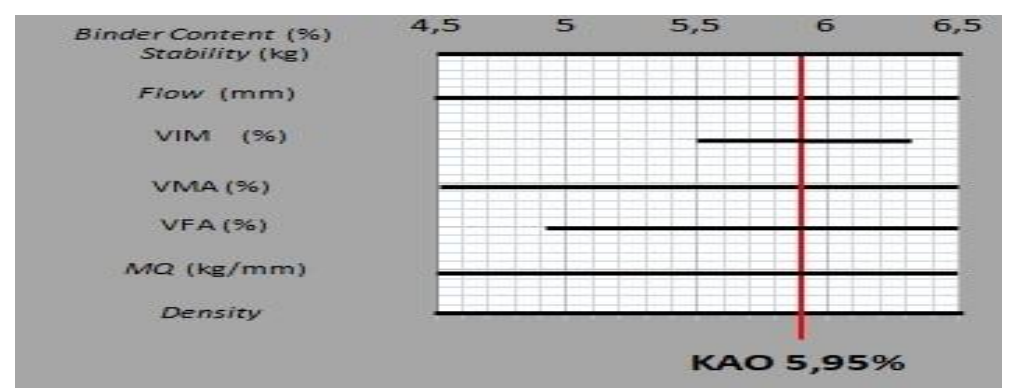

Gambar 8. Penentuan nilai KAO

Dari hasil analisis grafik 8. Barchart hubungan kadar aspal dengan karakteristik campuran digunakan nilai tengah pada grafik yang memenuhi karakteristik Marshal Test, sehingga diperoleh KAO sebesar 5,95\%. (1) Kadar Aspal Optimum (KAO) pada suatu campuran mempengaruhi karakteristik campuran aspal seperti Density, Void In Mix (VIM), Void In Material Agregates (VMA), Void Filled with Asphalt (VFA), Stability, Flow, dan Marshall Quotient. Dimana VIM menurun secara konsisten dengan bertambahnya kadar aspal. VFA secara konsisten bertambah dengan bertambahnya kadar aspal. Stability naik dengan bertambahnya kadar aspal sampai batas tertentu kemudian turun. Flow secara konsisten terus naik dengan bertambahnya kadar aspal. Marshall Quotient bertambah dengan bertambahnya kadar aspal sampai batas tertentu kemudian menurun. Nilai kadar aspal optimum (KAO) yang akan digunakan pada perencanaan campuran AC - WC dengan variasi bahan tambah filler abu marmer dan abu sekam padi dengan variasi kadar filler $0,0 \%, 0,5 \%$, $1 \%, 1,5 \%$, dan $2,0 \%$.

\subsection{Hasil Pengujian Indirect Tensile Strength (ITS) terhadap Penggunaan Bahan Tambah berdasarkan KAO}

a. Hubungan Indirect Tensile Strength (ITS) terhadap Variasi Filler berdasarkan KAO

Definisi Kekuatan Tarik atau Nilai ITS (Indirect Tensile Strength) adalah kemampuan bahan untuk menerima beban tarik tanpa mengalami kerusakan dan dinyatakan sebagai tegangan maksimum sebelum putus. Beban yang diberikan secara terus-menerus akan mengakibatkan tegangan (stress) yang akan diikutidengan kenaikan regangan sampai pada regangan (strain) tertentu, yaitu keadaan saat benda uji mulai retak sehingga terjadi tegangan maksimum. Pada Tabel 2. Merupakan data yang digunakan untuk mendapatkan nilai ITS (Indirect Tensile Strength) dari campuran aspal beton dengan menggunakan bahan tambah filler abu marmer dan abu sekam, sehingga didapatkan rekapitulasi nilai ITS pada (Tabel 2). Tabel 2. Rekapitulasi nilai ITS (Indirect Tensile Strength) pada KAO dengan masing-masing variasi kadar filler:

\begin{tabular}{|c|c|c|}
\hline \multirow{2}{*}{$\begin{array}{c}\text { Kadar Filler } \\
(\%)\end{array}$} & \multicolumn{2}{|c|}{$\begin{array}{c}\text { Nilai ITS (Indirect Tensile Strength) } \\
(\mathrm{KPa})\end{array}$} \\
\hline & Abu Marmer & Abu Sekam \\
\hline 0,0 & 10866,63 & 10866,63 \\
\hline 0,5 & 11902,79 & 11607,40 \\
\hline 1,0 & 12241,90 & 11789,33 \\
\hline 1,5 & 12174,08 & 11498,24 \\
\hline 2,0 & 11461,94 & 10806,89 \\
\hline
\end{tabular}

Nilai Kuat Tarik Tidak Langsung ITS (Indirect Tensile Strength) dari tiap-tiap variasi kadar filler abu marmer dan abu sekam yang digunakan dapat dilihat pada (Grafik 9). 


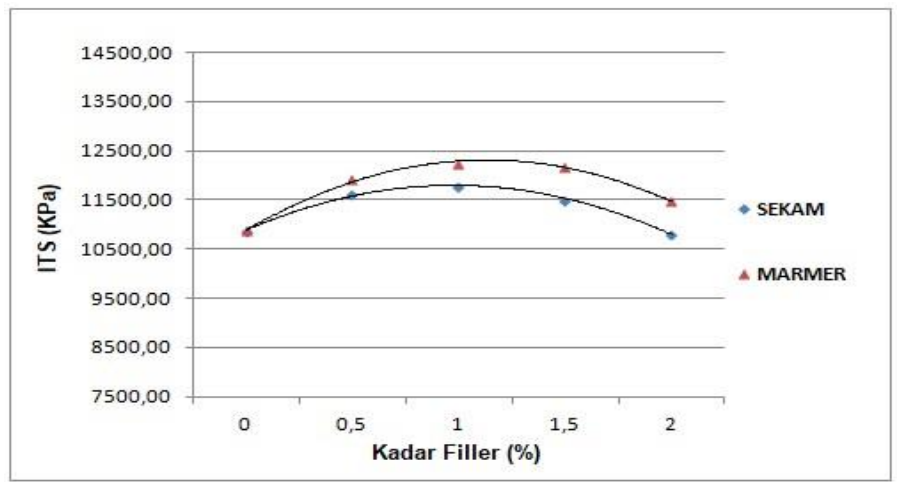

Gambar 9. Hubungan ITS terhadap bahan tambah abu Marmer dan abu sekam

Berdasarkan Grafik 9. Pada persentase kadar filler abu sekam dan marmer yaitu 0,0\%, 0,5\%, 1,0\%, 1,5\%, dan 2,0\% terlihat pada setiap penambahan kadar filler abu sekam, kuat Tarik mengalami peningkatan padakadarfiller0,5\%hingga kadar filler1,0\%lalu kuat tarik mengalami penurunan pada kadar filler 1,5\% hingga pada kadar filler 2,0\%. Begitu juga dengan marmer pada setiap penambahan kadar filler 0,5\%, kuat tarik mengalami peningkatan pada kadar filler 0,5\% hingga kadar filler 1,0\% lalu kuat tarik mengalami penurunan pada kadar filler 1,5\% hingga pada kadar filler 2,0\%. Kuat tarik akan mengalami peningkatan ketika campuran diberibahan tambah filler tetapi hanya pada kadar filler yang optimum atau pas. Karena apabila kadar filler berlebihan, maka campuran akan menjadi kaku.

b. Hubungan Regangan $(\varepsilon)$ terhadap Variasi Filler berdasarkan KAO

Dari hasil pengujian ITS di dapatkan nilai Regangan $(\mathcal{E})$ pada campuran. Regangan merupakan perubahan benda karena gaya dari luar dibandingkan denganukuran semula. Pada tabel 3. Merupakan data yang digunakan untuk mendapatkan nilai Regangan $(\varepsilon)$ dari campuran aspal beton dengan menggunakan bahan tambah filler abu marmer dan abu sekam, sehingga didapatkan rekapitulasi nilai Regangan $(\varepsilon)$ (Tabel3).

Tabel 3. Rekapitulasi nilai regangan $(\varepsilon)$ padaKAO dengan masing-masing variasi kadar filler.

\begin{tabular}{ccc}
\hline Kadar & \multicolumn{2}{c}{ Nilai Regangan $(\varepsilon)$} \\
\cline { 2 - 3 } Filler (\%) & Abu Marmer & Abu Sekam \\
\hline 0,0 & 0,01226 & 0,01226 \\
0,5 & 0,01529 & 0,01663 \\
1,0 & 0,01625 & 0,01843 \\
1,5 & 0,01381 & 0,01579 \\
2,0 & 0,00969 & 0,01124 \\
\hline
\end{tabular}

Nilai rekapitulasi Regangan dari tiap-tiap variasi kadar filler abu marmer dan abu sekam yang digunakan dapat dilihat pada (Grafik 10).

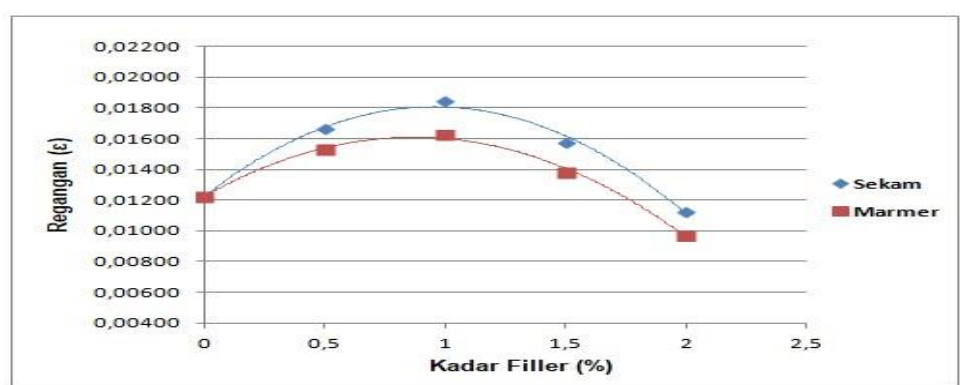

Gambar 10. Hubungan reganan ( $(\varepsilon)$ terhadap bahan tambah abu marmer dan abu sekam

Berdasarkan Grafik 10. Persentase kadar filler 0,0\%, 0,5\%, 1,0\%, 1,5\%, dan 2,0\%yaitu nilai regangan mengalami peningkatan pada kadar filler 0,5\% hingga kadar aspal 1,0\% kemudian pada kadar aspal 11,5\% nilai regangan mengalami penurunan hingga kadar aspal 2,0\%. Jadi apabila kadar filler bahan tambah yang digunakan untuk campuran berlebihan, maka nilai regangan akan menurun. 
Studi Perbandingan Kuat Tarik Tidak Langsung terhadap Campuran Aspal Beton dengan menggunakan Limbah Marmer dan Abu Sekam Padi sebagai Filler

St. Fauziah Badaron, Alimin Gecong, Muh. Kasim Anies, Wahyuni Meydinia Aunila Achmad, Eka Putri Setiani

c. Hubungan Modulus Elastis (E) terhadap Variasi Filler berdasarkan KAO

Modulus Elastis merupakan hubungan dari tegangan dan regangan yang menunjukkan kekakuan dari suatu bahan, setelah nilai tegangan dan regangan dari campuran diperoleh, sehingga dapat dihitung nilai Modulus Elastis dari campuran. Modulus elastis merupakan factor yang sangat penting yang akan mempengaruhi kinerja perkerasan aspal karena apabila nilai modulus elastis rendah maka perkerasan mudah retak saat menerima beban yang berat Pada Tabel 2 dan Tabel 3 merupakan data yang digunakan untuk mendapatkan nilai Modulus Elastis dari campuran aspal beton dengan menggunakan bahan tambah filler abu marmer dan abu sekam dengan persentase kadar filler $0,0 \%, 0,5 \%, 1,0 \%, 1,5 \%$, dan 2,0\% pada tiap-tiap campuran sehingga didapatkan rekapitulasi nilai Modulus Elastis yang terdapat pada(Tabel 3.4).

Tabel 4. Rekapitulasi nilai modulus elastic pada KAO dengan masing masing variasi kadar filler

\begin{tabular}{ccc}
\hline \multirow{2}{*}{$\begin{array}{c}\text { Kadar Filler } \\
\text { (\%) }\end{array}$} & \multicolumn{2}{c}{$\begin{array}{c}\text { Nilai Modulus Elastis } \\
\text { (KPa) }\end{array}$} \\
\cline { 2 - 3 } & Abu Marmer & Abu Sekam \\
\hline 0,0 & 886487,96 & 886487,96 \\
0,5 & 778362,08 & 697919,44 \\
1,0 & 753148,52 & 639734,73 \\
1,5 & 881257,77 & 728392,86 \\
2,0 & 1182775,05 & 961440,42 \\
\hline
\end{tabular}

Nilai Modulus Elastis dari tiap-tiap variasi kadar filler abu marmer dan abu sekam yang di gunakan dapat dilihat pada (Grafik 11).

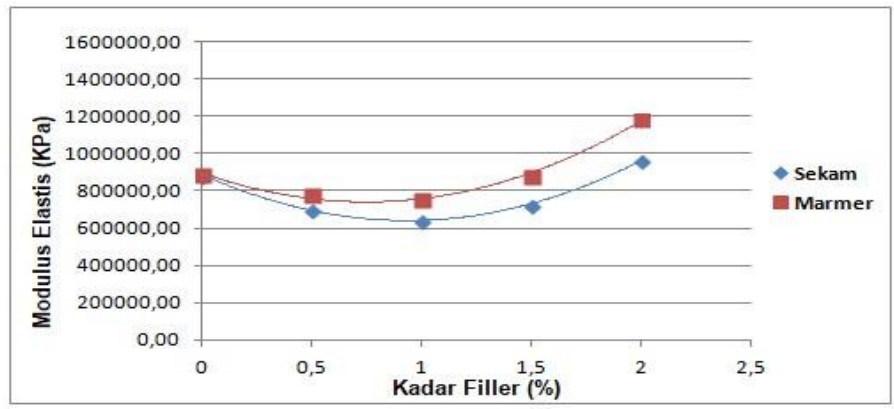

Grafik 11. Hubungan modulus elastic terhadap bahan tambah abu marmer dan abusekam

Berdasarkan Grafik 11. Hubungan modulus elastic terhadap bahan tambah filler abu marmer dan abu sekam pada persentase kadar filler $0,5 \%$ nilai modulus elastis mengalami penurunan hingga kadar aspal 1,0\% kemudian pada kadar aspa 11,5\% nilai modulus elastis mengalami peningkatan hingga kadar aspa $12,0 \%$. Apabila kadar filler bahan tambah yang di gunakan berlebihan, maka nilai modulus elastic akan semakin tinggi. Penggunaan abu marmer dan abu sekam sebagai filler yang berlebihan dapat meningkatkan nilai modulus elastis. Hubungan antara modulus elastis denganregangan yaitu berbanding terbalik, apabila semakin tinggi nilai modulus elastic maka semakin rendah nilai regangan.

\subsection{Pembahasan Indirect Tensile Strength (ITS) terhadap Penggunaan Bahan Tambah berdasarkan KAO}

a. Pengaruh Filler Abu Marmer dan Abu Sekam terhadap Indirect Tensile Strength (ITS)

Penggunaan abu marmer dan abu sekam sebagai filler dapat meningkatkan nilai kuat tarik. Hal itu dikarenakan pada abu marmer terdapat unsure kimia berupa Kalsium Oksida $(\mathrm{CaO})$ sebesar 52,69\% yang hamper sama dengan semen. Dalam pengujian ini, didapatkan kadar filler yang optimum untuk penggunaan abu marmer yaitu1,0\%dengan nilai kuat tarik 12241,90 KPa. Pada abu sekam padi juga terdapat unsure kimia berupa silica reaktif sekitar $85 \%$ - 90\%. Penambahan abu sekam padi pada filler campuran juga dapat meningkatkan kuat tarik, namun kuat tarik yang didapatkan tidak sebesar apabila menggunakan abu marmer. Pada penggunaan abu sekam padi pada kadar filler optimum yaitu 1,0\% didapatkan nilai kuat tarik 
sebesar11789,33KPa. Oleh karena itu abu marmer dan abu sekam padi bias digunakan sebagai bahan tambah pada campuran untuk bahan pengisi atau filler karena dapat meningkatkan nilai kuat tarik agar campuran lebih kuat dalam memikul beban lalu lintas dan campuran juga menjadi lebih fleksibel, tetapi hanya pada kadar filleryang optimum atau pas. Karena apabila berlebihan, maka campuran akan menjadi kaku sehingga campuran akan lebih mudah retak atau hancur.

\section{b. Pengaruh Filler terhadap Regangan}

Pengaruh abu marmer dan abu sekam padi sebagai filler terhadap regangan yaitu dapat meningkatkan nilai regangan, namun seiring bertambahnya kadar filler, nilai regangan akan semakin kaku. Apabila nilai regangan mulai mengikat, maka benda uji mulai mengalami retak atau keruntuhan sehingga secara perlahan nilai regangan akan menurun. Hubungan antara kuat tarik terhadap regangan yaitu apabila semakin tinggi kuat tarik maka semakin rendah regangan. Karena campuran lebih mampu menahan beban tarik sehingga regangan yang terjadi pada campurantidak terlalu besar.

c. Pengaruh Filler terhadap Modulus Elastis

Penggunaan abu marmer dan abu sekam padi sebagai filler yang berlebihan dapat meningkatkan nilai modulus elastis. Hubungan antara modulus elastis dengan regangan yaitu berbanding terbalik, apabila semakin tinggi nilai modulus elastic maka semakin rendah nilai regangan. Karena apabila nilai modulus elastis tinggi, maka campuran lebih sulit mengalami perubahan bentuk. Hal ini juga diakibatkan karena sifat modulus elastic yang dapat berubah akibat penambahan paduan dan perlakuan panas.

\begin{tabular}{|c|c|c|c|}
\hline Parameter & $\begin{array}{l}\text { Abu Marmer } \\
\text { (AM) }\end{array}$ & $\begin{array}{l}\text { Abu Sekam } \\
\text { (AS) }\end{array}$ & Hasil \\
\hline $\begin{array}{l}\text { Kuat Tarik } \\
\text { Tidak } \\
\text { Langsung } \\
(\sigma)\end{array}$ & $\begin{array}{l}\text { Dari pengujian kuat } \\
\text { tarik tidak langsung, } \\
\text { campuran dengan } \\
\text { menggunakan filler abu } \\
\text { marmer } \\
\text { menahan mampu } \\
\text { sebesar } 11729,47 \mathrm{Kpan}\end{array}$ & $\begin{array}{l}\text { Dari pengujian kuat } \\
\text { tarik tidak langsung, } \\
\text { campuran yang } \\
\text { menggunakan filler abu } \\
\text { sekam mampu } \\
\text { menahan } 11313,70 \mathrm{KPa} \\
\text { sebesar } 113 .\end{array}$ & $\sigma A M>\sigma A S$ \\
\hline$\underset{(\varepsilon)}{\text { Regangan }}$ & $\begin{array}{ll}\begin{array}{l}\text { Nilai regangan yang } \\
\text { didapatkan }\end{array} & \begin{array}{r}\text { dari } \\
\text { campuran }\end{array} \\
\text { yang } \\
\text { menggunakan filler abu } \\
\text { marmer yaitu } 0,02244\end{array}$ & $\begin{array}{l}\text { Nilai regangan yang } \\
\text { didapatkan } \\
\text { campuran } \\
\text { menggunakan filler abu } \\
\text { sekam yaitu } 0,02478\end{array}$ & $\varepsilon A M<\varepsilon A S$ \\
\hline $\begin{array}{l}\text { Modulus } \\
\text { Elastis } \\
\text { (E) }\end{array}$ & $\begin{array}{l}\text { Nilai modulus elastis } \\
\text { dari penggunaan filler } \\
\text { abu marmer yaitu } \\
896406,28 \mathrm{KPa} \text {. }\end{array}$ & $\begin{array}{l}\text { Nilai modulus elastis } \\
\text { dari penggunaan filler } \\
\text { abu marmer yaitu } \\
782795,08 \mathrm{KPa} \text {. }\end{array}$ & $E_{A M}>E_{A S}$ \\
\hline
\end{tabular}

Dari tabel 5. Dapat dilihat bahwa hasil dari perhitungan kuat tarik tidak langsung pada Benda uji abu marmer menghasilkan nilai lebih besar dari benda uji dengan campuran abu sekam, dengan nilai perbandingan sebesar 2,91\%. Hal ini disebabkan karena abu marmer mampu menahan beban yang diberikan lebih besar dibanding abu sekam padi. Nilai regangan menunjukan bahwa benda uji dengan menggunakan campuran abu marmer menghasilkan nilai regangan yang lebih kecil dari benda uji yang menggunakan campuran sekam padi. Dengan perbedaan sebesar 7,94\%. Hal ini dikarenakan abu marmer lebih mampu menahan kuat tarik dibandingkan abu sekam padi sehingga regangan yang terjadi juga kecil. Nilai modulus elastis dari benda uji menunjukan bahwa benda uji dengan campuran abu marmer menghasilkan nilai modulus elastis lebih besar dari benda uji menggunakan abu sekam padi dengan perbedaan sebesar 10,53\%. Hal ini dikarenakan campuran dengan bahan abu marmer mengalami regangan yang kecil sehingga campuran lebih elastis.

\section{PENUTUP}

\subsection{Kesimpulan}

Berdasarkan hasil penelitian campuran aspal beton dengan penggunaan bahan tambah filler abu marmer dan abu sekam dapat disimpulkan sebagai berikut: Dari kadar aspal rencana didapatkan kadar aspal optimum dengan cara mengambil nilai tengah yaitu 5,95\% yang digunakan pada pengujian selanjutnya yaitu kuat tarik tidak langsung (Indirect Tensile Strength). Dari pengujian yang telah dilakukan maka dapat disimpulkan bahwa abu marmer merupakan filler yang baik untuk digunakan sebagai bahan tambah dibandingkan dengan abu sekam. Karena, abu marmer mampu menahan kuat tarik lebih dari abu sekam sehingga jalan lebih kuat memikul beban lalu lintas. 
Studi Perbandingan Kuat Tarik Tidak Langsung terhadap Campuran Aspal Beton dengan menggunakan Limbah Marmer dan Abu Sekam Padi sebagai Filler

St. Fauziah Badaron, Alimin Gecong, Muh. Kasim Anies, Wahyuni Meydinia Aunila Achmad, Eka Putri Setiani

\subsection{Saran}

Berdasarkan hasil penelitian diusulkan beberapa saran sebagai berikut: Penelitian ini diharapkan dapat dikembangkan lebih lanjut untuk menelitilebih mendalam pengaruh penggunaan abu marmer dan abu sekam padi sebagai filler pada Lataston, Latasir, maupun jenis lapisan perkerasan lain serta kepadatan mutlak. Disarankan untuk penelitian selanjutnya untuk meneliti dengan menggunakan jenis aspal yang lebih bervariasi untuk lebih mengetahui pengaruh bahan tambah abu marmer dan abu sekam dengan jenis aspal yang berbeda. Penelitian ini diharapkan dapat lebih dikembangkan untuk penelitian selanjutnya terhadap karakteristik campuran yang berbeda dengan menggunakan abu marmer atau abu sekam padi sebagai filler.

\section{DAFTAR PUSTAKA}

AASHTO, 1982. Standart Spesification For Transportation Material sand Method of Sampling and Testing, Part I: Specification.

ASTMD2726-04. Standard Test Method for Bulk Specific Gravity and Density of Non-Absorptive Compacted Bituminous Mixtures

Ahmad, Malik. 2010. Kajian Karakteristik Indirect Tensile Strength Asphalt Concrete Recycle Dengan Campuran Aspal Penetrasi 60/70 dan Residu Oli pada Campuran Hangat.

Brown, Stephen. 1990. The Shell Bitumen Handbook.Chertsey: Shell Bitumen U.K.

Garrick, N.W., \&Biskur, R. R. 1990. Effects of Asphalt Properties on Indirect Tensile Strength

Irwan, Putri Auliah \& Dea Resky Nawir. 2017. Pengaruh Model Perlakuan Serat Ijuk dengan Perendaman Air Laut terhadap Karakteristik Campuran Beton Aspal

Laboratorium Transportasi dan Jalan Raya. 2008. Petunjuk Pelaksanaan Praktikum Bahan Perkerasan Jalan Raya. Jurusan Teknik Sipil Universitas Muslim Indonesia Makassar

Manuruki, Ince Hikma \& Ahmad Affandi Rahman. 2016. Analisis Penggunaan Material Komposit Fly Ash dan Abu Sekam Padi Terhadap Campuran Aspal Beton.

Prasetyoko, D. 2001. Pengoptimuman Sintesis Zeolit daripada Silika Abu Sekam Padi Pencirian dan Tindak Balas Pemangkinan Friedel Crafts

SKBI-2.4.26, 1987. Petunjuk Pelaksanaan Lapis Aspal Beton (laston) Untuk Jalan Raya.

Sukirman, Silvia. 2003. Beton Aspal Campuran Panas. Jakarta: Penerbit Granit.

Sulaiman, Lusman (2018). Evaluasi Kuat tekan Beton recycle Agregat Dengan Campuran Air Laut dan Prediksi Modulus Elastisitasnya. PENA TEKNIK: Jurnal Ilmiah Ilmu-ilmu Teknik 3(1). 25 - 36.

Sulaiman, Lusman \& Nurhidayah (2018). Analisis Perbandingan Kuat Tekan Mortar dari Material Pasir Putih dan Pasir Biasa Sungai Masamba. PENA TEKNIK: Jurnal Ilmiah Ilmu-ilmu Teknik 3(2). 207-218.

Sulaeman, Budiawan (2018). Modulus Elastisitas Berbagai Jenis Material. PENA TEKNIK: Jurnal Ilmiah Ilmuilmu Teknik 3(2). 127 - 138.

Sulaksono W, Sony. 2001. Rekayasa Jalan. Bandung: Institut Teknologi Bandung.

Wijaya, Ardyansah \& Muhammad Ali. 2015. Pengaruh Variasi Perendaman Terhadap Durabilitas Campuran Aspal Beton dengan Menggunakan Bottom Ash dan Fly Ash sebagai Filler.

Zulkifli, dkk. 2012. Kajian Laboratorium Limbah Marmer Sebagai Filler Dalam Campuran Aspal Aspal Beton Lapisan Antara $(A C-B C)$. 